\title{
Diversity analysis, identification, and bioprospecting of Lactic Acid Bacteria (LAB) isolated from Sumbawa horse milk
}

\author{
KHADIJAH ALLIYA FIDIEN ${ }^{1}$, BASO MANGUNTUNGI ${ }^{1}$, LINDA SUKMARINI ${ }^{2, \bullet}$, APON ZAENAL MUSTOPA ${ }^{2}$, \\ LITA TRIRATNA ${ }^{2}$, FATIMAH ${ }^{3}$, KUSDIANAWATI ${ }^{1}$ \\ ${ }^{1}$ Department of Biotechnology, Faculty of Biotechnology, Universitas Teknologi Sumbawa. Jl. Raya Olat Maras, Moyo Hulu, Sumbawa 84371, West \\ Nusa Tenggara, Indonesia \\ ${ }^{2}$ Research Center for Biotechnology, Indonesian Institute of Sciences. Jl. Raya Jakarta-Bogor Km 46, Cibinong, Bogor 16911, West Java, Indonesia. \\ Tel.: +62-21-8754587, Fax.: +62-21-8754588, `email: linda.sukmarini@lipi.go.id \\ ${ }^{3}$ Indonesian Center for Agricultural Biotechnology and Genetic Resources Research and Development. Jl. Tentara Pelajar No. 3A, Cimanggu, Bogor \\ 16111, West Java, Indonesia
}

Manuscript received: 25 April 2021. Revision accepted: 24 May 2021.

\begin{abstract}
Fidien KA, Manguntungi B, Sukmarini L, Mustopa AZ, Triratna L, Fatimah, Kusdianawati. 2021. Diversity analysis, identification, and bioprospecting of Lactic Acid Bacteria (LAB) isolated from Sumbawa horse milk. Biodiversitas 22: $3333-3340$. Sumbawa horse milk has a probiotic potential because of the presence of Lactic Acid Bacteria (LAB). The LAB present in Sumbawa horse milk has been reported to have antimicrobial activities against pathogenic bacteria, including Staphylococcus epidermidis, Staphylococcus aureus, Escherichia coli, and Vibrio cholerae. However, the potential of LAB from Sumbawa horse milk as antioxidant and antidiabetic is still unexplored. Studies related to the diversity of indigenous bacteria in Sumbawa horse milk based on metagenomic analysis have not been widely studied either. Therefore, this study aimed to determine the diversity of species of indigenous bacteria in Sumbawa horse milk and to identify LAB bioprospecting from Sumbawa horse milk. The diversity of indigenous bacterial species was investigated by the 16S rRNA gene-targeted metagenomic approach from bacterial DNA isolated from Sumbawa horse milk. The identification of LAB was also carried out by the 16S rRNA gene identification method. LAB bioprospecting on antioxidant activity was determined using the DPPH method, while the antidiabetic activity was measured using the $\alpha$-glucosidase inhibition assay. The diversity analysis of indigenous bacteria based on 16S rRNA gene-based metagenomic revealed at least 7 phyla were relatively abundant in Sumbawa horse milk. The greatest abundance was shown by the phylum Proteobacteria $(0.641 \%)$ and Firmicutes $(0.327 \%)$. Enterococcus durans (39.01\%) was the species that had the highest abundance in Sumbawa horse milk, followed by Lactococcus garvieae (30.13\%) and Lactococcus lactis (19.85\%). Moreover, based on the identification of the 16S rRNA gene, eight LAB isolates had similarities to bacterial strains, including Enterococcus faecium DSM 20477, E. faecium NBRC 100486, E. faecium ATCC 19434, E. durans 98D, E. faecalis ATCC 19433, E. faecalis NRBC 100480, Lactococcus lactis subsp. hordniae NBRC 100931 and L. garvieae JCM 10343 with similarity levels of more than 98\%. In terms of LAB bioprospecting, the antioxidant assay showed the highest DPPH radical binding activity by $L$. garvieae L.22PR (43\%). Meanwhile, the highest inhibitory activity of $\alpha$-glucosidase was shown by $E$. faecium G.6PR (45\%).
\end{abstract}

Keywords: Bioprospection, diversity analysis, identification, metagenomics, Lactic Acid Bacteria, Sumbawa horse milk

\section{INTRODUCTION}

Sumbawa horse milk widely known as wild horse milk, is a special commodity from Sumbawa Island, West Nusa Tenggara, Indonesia. According to Sujaya et al. (2008a), Sumbawa horse milk has probiotic potential. It has been reported that this milk could increase cellular immunity against Salmonella thyphimurium infection (Reni et al. 2013). The presence of lactic acid bacteria (LAB) in Sumbawa horse milk provides beneficial health effects, such as growth modulation bacteria beneficial for health in the human digestion (Sujaya et al. 2012). Investigations on the diversity of indigenous bacteria in Sumbawa horse milk are still limited to LAB and its metabolites (Sujaya et al. 2008b; Setyowati et al. 2012; Nuraida 2015; Manguntungi et al. 2018). Moreover, the method used to identify bacteria present in this milk still depends on microbial cultivation. Metagenomics is a functional analysis method based on microbial DNA sequences in the sample (Handelsman
2004). Studies on the microbial community and metagenome functional analysis in milk have been conducted in human milk (Ward et al. 2013) and goat milk (Zhang et al. 2017a).

The study on LAB carried out by Sujaya et al. (2008b) revealed that the isolated LAB from Sumbawa horse milk was predominantly belongs to the Lactobacilli. Several LAB species that have been characterized include Lactobacillus acidophilus, Lb. brevis, Lb. plantarum, and Lactococcus lactis (Antara et al. 2009). Setyowati et al. (2012) and Manguntungi et al. (2018) reported that LAB isolated from Sumbawa horse milk had antimicrobial activity against pathogenic bacteria, including Staphylococcus epidermidis, $S$. aureus, Escherichia coli, and Vibrio cholerae. However, to the best of our knowledge, there has been no study yet on bioprospecting of other than antimicrobial activities of LAB from Sumbawa horse milk.

Thus, in this study, 16S rRNA gene-based metagenomic approach was employed to detect populations of 
indigenous species of bacteria found in Sumbawa horse milk. LAB identification from Sumbawa horse milk was also carried out to determine the isolated species. In addition, bioprospecting on antioxidant and antidiabetic activities was also assessed to uncover further the potential of LAB from Sumbawa horse milk.

\section{MATERIALS AND METHODS}

\section{Metagenomic DNA isolation of Sumbawa horse milk}

The metagenomic DNA was isolated from horse milk collected from the Penyaring Village, Sumbawa District, West Nusa Tenggara. Isolation was carried out following the manufacture's instruction of ZymoBIOMICSTM DNA Miniprep Kit (Zymo Research Corp.) with a slight modification. Briefly, a sample of $5 \mathrm{~mL}$ of Sumbawa horse milk was put into a $15 \mathrm{~mL}$ falcon and centrifuged at 2,000 $\mathrm{rpm}, 4^{\circ} \mathrm{C}$ for $10 \mathrm{~min}$. The supernatant was taken and centrifuged again at $6000 \mathrm{rpm}, 4^{\circ} \mathrm{C}$ for $10 \mathrm{~min}$. The pellet so collected was suspended with $750 \mu \mathrm{L}$ Lysis Solution, then transferred into the Lysis Tubes. The resuspension was then vortexed for $\geq 20$ minutes then centrifuged at $10,000 \mathrm{rpm}$ for $1 \mathrm{~min}$. A total of $400 \mu \mathrm{L}$ supernatant was transferred into a filter in a collection tube and centrifuged at $8,000 \mathrm{rpm}$ for $1 \mathrm{~min}$. A total of $1200 \mu \mathrm{L}$ DNA Binding Buffer was added and mixed well. A total of $800 \mu \mathrm{L}$ sample was transferred into the column and centrifuged at 10,000 rpm for $1 \mathrm{~min}$. The supernatant was then discarded. This stage was carried out twice. After that, a total of 400 $\mu \mathrm{L}$ Wash Buffer 1 was added to the column in a new collection tube and centrifuged for $10 \mathrm{~min}$, then the supernatant was removed. A total of $700 \mu \mathrm{L}$ Wash Buffer 2 was added to the column and centrifuged at 10,000 rpm for $1 \mathrm{~min}$ then the supernatant was removed. A total of $200 \mu \mathrm{L}$ Wash Buffer 2 was added back to the column on the Collection Tube and centrifuged at 10,000 rpm for $1 \mathrm{~min}$. The column was transferred into a $1.5 \mathrm{~mL}$ microtube, and $50 \mu \mathrm{L}$ DNase/RNase Free Water was added and then incubated for $1 \mathrm{~min}$ before centrifuged at $10,000 \mathrm{rpm}$ for 1 min. The eluted DNA was then confirmed by electrophoresis with $1 \%$ agarose in $1 \mathrm{x}$ TAE Running Buffer at a voltage of $100 \mathrm{~V}$. Sequencing was carried out by Novogene CO., Ltd, Japan using Next-Generation Sequencing (NGS) MiSeq instruments (Illumina, Inc.).

\section{Isolation of Lactic Acid Bacteria}

A total of $100 \mu \mathrm{L}$ Sumbawa horse milk was cultivated in $5 \mathrm{~mL}$ of M17 broth media with various sugars (lactose (L) and glucose $(\mathrm{G})$ ) and incubated at $30{ }^{\circ} \mathrm{C}$ overnight. Then, $100 \mu \mathrm{L}$ overnight culture was diluted with $900 \mu \mathrm{L}$ $0.85 \% \mathrm{NaCl}$ and resuspended. The $10^{-3}$ and $10^{-4}$ dilutions of M17 cultures were taken and spread on M17 Agar media with various sugars (lactose and glucose) and then incubated at $30{ }^{\circ} \mathrm{C}$ for $48 \mathrm{~h}$. A single colony was retrieved and cultivated in $\mathrm{M} 17$ broth, then incubated at $30^{\circ} \mathrm{C}$ for 16 $\mathrm{h}$ for later use in genomic DNA isolation.

\section{Genomic DNA isolation of Lactic Acid Bacteria}

The genomic DNA isolation was carried out according to the method developed by Doyle and Doyle (1990) with a slight modification. Bacterial cell pellet collection was performed by transferring $1.5 \mathrm{~mL}$ of the M17 broth culture to a microtube and centrifuge at $6,000 \mathrm{rpm}, 4{ }^{\circ} \mathrm{C}$ for 10 min. The supernatant was then removed. The pellets were suspended with $500 \mu \mathrm{L}$ TE Buffer $\mathrm{pH} 8.0$ containing 60 $\mathrm{mg} / \mathrm{mL}$ lysozyme, then incubated at $37^{\circ} \mathrm{C}$ for $1 \mathrm{~h}$. After incubation, $200 \mu \mathrm{L} 10 \%$ SDS, $100 \mu \mathrm{L} 5 \mathrm{M} \mathrm{NaCl}$, and 80 $\mu \mathrm{L} 10 \% \mathrm{CTAB}$ were added and the mixture was incubated at $60^{\circ} \mathrm{C}$ for $30 \mathrm{~min}$ (inverted every $10 \mathrm{~min}$ ). A total of 500 $\mu \mathrm{L}$ chloroform was added and then centrifuged at 13,000 $\mathrm{rpm} 4^{\circ} \mathrm{C}$ for $15 \mathrm{~min}$. The supernatant was transferred into a new microtube and $0.6 \mathrm{x}$ volume isopropanol was added, then incubated at $-20^{\circ} \mathrm{C}$ for $2 \mathrm{~h}$. After centrifugation at $13,000 \mathrm{rpm} 4^{\circ} \mathrm{C}$ for $10 \mathrm{~min}$, the supernatant was removed and the pellet was washed with $1 \mathrm{~mL}$ of $70 \%$ ethanol. The DNA pellet was then dried overnight before dissolved using $27 \mu \mathrm{L} \mathrm{ddH}_{2} \mathrm{O}$ and $3 \mu \mathrm{L}$ RNase $(1 \mathrm{mg} / \mathrm{mL})$ and incubated at $37^{\circ} \mathrm{C}$ for $60 \mathrm{~min}$.

\section{Polymerase Chain Reaction (PCR) amplification of $16 \mathrm{~S}$ rRNA gene}

Amplification of the 16S rRNA gene was performed using a thermal cycler. Each PCR reaction $(50 \mu \mathrm{L})$ containing: $2.5 \mu \mathrm{L}$ of $100 \mathrm{ng}$ DNA template; $1 \mu \mathrm{L}$ for each $10 \mathrm{mM}$ primer; $1 \mu \mathrm{L}$ My Taq DNA Polymerase (Bioline), $10 \mu \mathrm{L} 5 \mathrm{x}$ My Taq Hs Red Buffer (Bioline), and $34.5 \mu \mathrm{L}$ $\mathrm{ddH}_{2} \mathrm{O}$. Oligonucleotides for bacterial PCR 16S rRNA include forward $8 \mathrm{~F}$ primer (5'-AGA GTT TGA TCA TGG CTC AG-3 ') and 15R reverse primer (5'-AAG GAG GTG ATC CAA CCG CA-3'). The PCR conditions used were as follows: pre-denaturation for 5 minutes at $95^{\circ} \mathrm{C}$, denaturation at $95^{\circ} \mathrm{C}$ for $1 \mathrm{~min}$, annealing at $58^{\circ} \mathrm{C}$ for 1 min, an extension at $72^{\circ} \mathrm{C}$ for $30 \mathrm{sec}$, and a final extension at $72^{\circ} \mathrm{C}$ for $7 \mathrm{~min}$. PCR was carried out in 35 cycles. PCR products were electrophoresed on $1 \%$ agarose gel in TAE 1 $\mathrm{x}$ Running Buffer at $100 \mathrm{~V}$ and stained with ethidium bromide. Electrophoresis gel was visualized with a UV-Vis transilluminator. The $1 \mathrm{~kb}$ DNA ladder marker was used to estimate the size of the DNA fragments. Sequencing for identifying $16 \mathrm{~S}$ rRNA bacteria was carried out by $1^{\text {st }}$ Base DNA sequencing service (Axil Scientific Pte Ltd.) The sequencing results were analyzed using MegaX and BLAST software.

\section{Antioxidant activity assay}

The ability of LAB as an antioxidant agent was determined by the 2,2-diphenyl-1-picrylhydrazyl (DPPH) method (Shimada et al. 1992) with a slight modification. A total of $20 \mu \mathrm{L}$ supernatant metabolites and $180 \mu \mathrm{L} \mathrm{DPPH}$ solution $(0.2 \mathrm{mM}$ in methanol) were mixed in a microplate and incubated for $30 \mathrm{~min}$ in a dark condition. A growth medium was used as a blank, while vitamin C $(50 \mathrm{mg} / \mathrm{mL})$ was a positive control. After incubation, the DPPH concentration was measured using a multiplate reader (Thermo Scientific) with an absorbance at $540 \mathrm{~nm}$. The color change was caused by the reduction of DPPH to diphenylpicrylhydrazine, which is a non-radical compound. The remaining DPPH molecules were read for their absorbance at $540 \mathrm{~nm}$ after $30 \mathrm{~min}$ of incubation. 


\section{$\alpha$-glucosidase inhibition assay}

Inhibition of $\alpha$-Glucosidase was determined by the method adopted from Zahratunnisa et al. (2017). Briefly, $15.51 \mu \mathrm{L}$ (equivalent to $14.5 \alpha$-glucosidase enzyme units) of $\alpha$-glucosidase was diluted with the addition of a phosphate buffer $\mathrm{pH} 6.8$ ) up to $5 \mathrm{~mL}$ volume. The reaction mixture of the $\alpha$-glucosidase inhibition assay consisting of $30 \mu \mathrm{L}$ sample, $36 \mu \mathrm{L}$ phosphate buffer $\mathrm{pH} 6.8$, and $17 \mu \mathrm{L}$ p-nitrophenyl- $\alpha$-D-glucopyranoside/PNPG (5 mM). After pre-incubation at $39{ }^{\circ} \mathrm{C}$ for $5 \mathrm{~min}, 17 \mu \mathrm{L} \alpha$-glucosidase $\left(0.045\right.$ units $/ \mathrm{mL}$ ) was added and incubated at $39{ }^{\circ} \mathrm{C}$ for 15 min. The reaction was then stopped by adding $100 \mu \mathrm{L}$ $\mathrm{Na}_{2} \mathrm{CO}_{3}(200 \mathrm{mM})$. The inhibition of $\alpha$-glucosidase was measured at $405 \mathrm{~nm}$. Acarbose was used as a positive control of $\alpha$-glucosidase inhibition. The antidiabetic potential of each LAB isolate in Sumbawa horse milk was measured by calculating the inhibitory activity of the crude extract of LAB against the $\alpha$-glucosidase enzyme.

\section{Data analysis}

The data of antioxidant activity assay and $\alpha$-glucosidase inhibition assay obtained were then analyzed using One Way ANOVA with Duncan's continued test using an $\alpha$ value of 0.05 .

\section{RESULTS AND DISCUSSION}

\section{Diversity analysis of the indigenous bacteria of \\ Sumbawa horse milk}

Analysis of the diversity of bacteria indigenous Sumbawa horse milk was performed on samples from Penyaring Village, Sumbawa District, West Nusa
Tenggara, Indonesia. The diversity of phyla based on taxa phylum obtained from the NGS analysis showed differences in the relative abundance of each phylum in the sample of Sumbawa horse milk (Figure 1). The largest relative abundance belonged to Proteobacteria $(0.641 \%)$ and Firmicutes $(0.327 \%)$.

The bacterial community profile based on the 10 genera with the greatest abundance $(33.13 \%)$ is shown in a taxonomic tree (Figure 2). It shows the abundance of bacterial communities in Sumbawa horse milk at the phylum level detected, including Firmicutes, Bacteriotedes, Fusobacteria, and Proteobacteria. The class of the Proteobacteria detected was gamma-proteobacteria. Compare to other classes, Bacilli was the most detected bacteria. Furthermore, the orders detected with the largest to the smallest relative abundance were Lactobacillales, Bacillales, Bacteriodales, Clostridiales, Enterobacteriales, and Fusobacteriales.

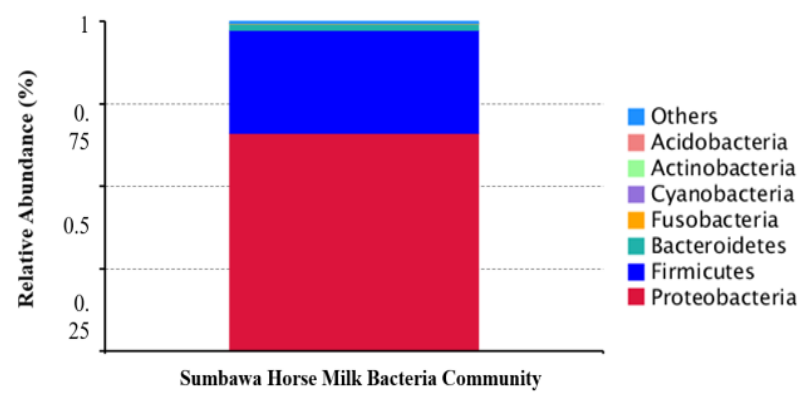

Figure 1. Composition of the Sumbawa horse milk bacteria community

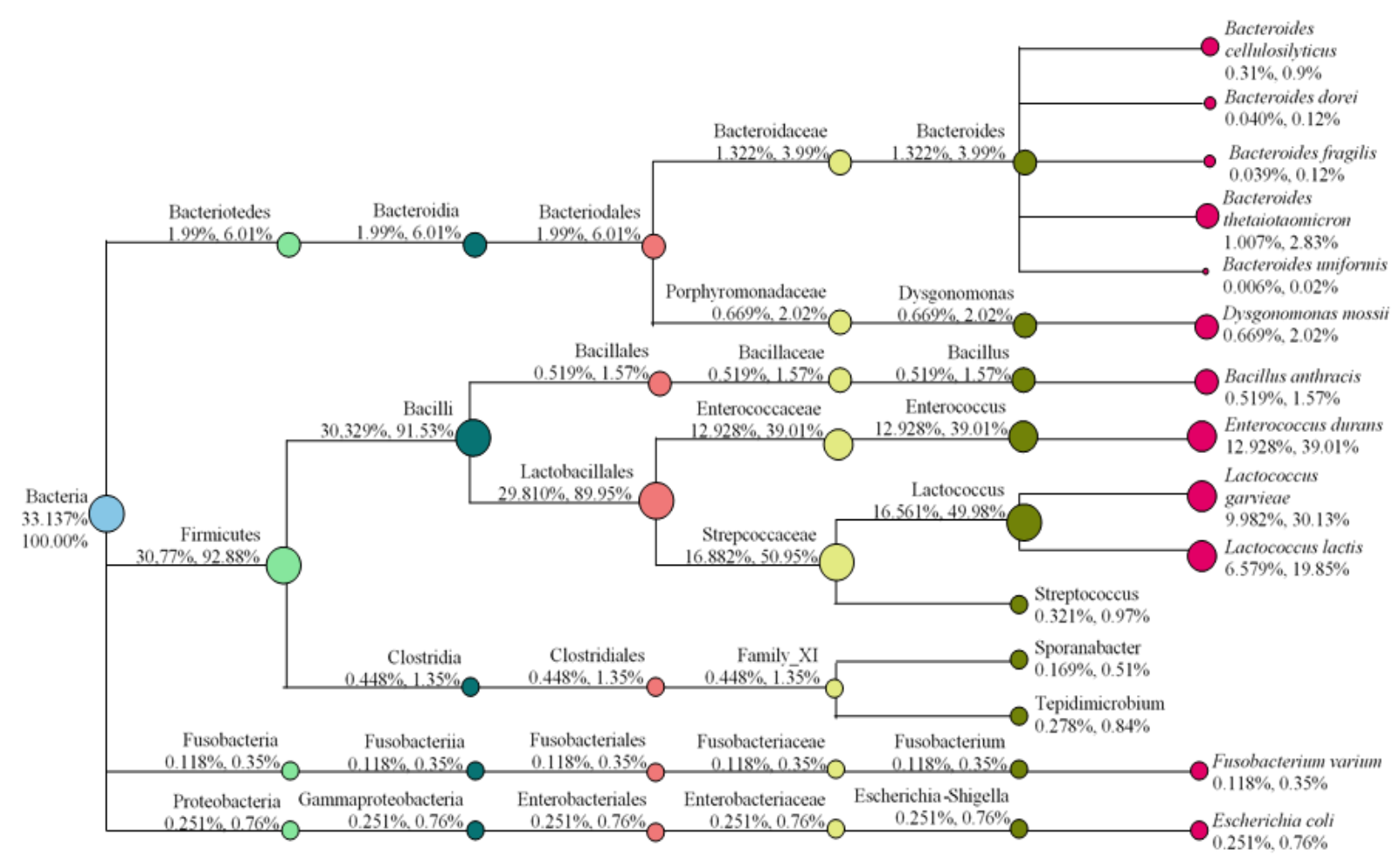

Figure 2. Taxonomic tree of indigenous bacteria of Sumbawa horse milk 
Identification of LAB isolated from Sumbawa horse milk

LAB identification was carried out using bacterial isolates obtained from horse milk samples Sumbawa horse milk in Sumbawa District, West Nusa Tenggara is mainly produced in Penyaring and Lenangguar villages. The sample collection of Sumbawa horse milk from different locations aimed to compare LAB distribution from these two regions. The morphology of the LAB colony grown on the media was verified based on shape, edges, and color. The colonies obtained from the isolation were round, smooth edges, and white. The morphology of these isolates was in accordance with the morphology of LAB reported by Laily et al. (2013).

Identification of LAB in Sumbawa horse milk was carried out by a molecular analysis based on the $16 \mathrm{~S}$ rRNA gene. Based on the results of electrophoresis, the amplified DNA fragment was about $1500 \mathrm{bp}$. The sequencing results of LAB identification using $16 \mathrm{~S}$ rRNA sequence were as follows (Table 1).

As seen in Table 1, eight identified LAB isolates from Sumbawa horse milk were from two bacterial genera, namely Enterococcus and Lactococcus. Six LAB isolates G.5PR, G.6PR, G.18LG, G.20LG, G.19PR, and L.24PR have similarities with E. faecium NBRC 100486 (99.18\%), E. faecium DSM 20477 (99.59\%), E. durans 98D (99.1\%), E. faecium ATCC 19434 (99.45\%), E. faecalis ATCC 19433 (99.05\%), and E. faecalis NBRC 100480 (98.95\%), respectively. While two isolates L.19G and L.22PR shared
99.93\% and $98.40 \%$ identities with L. lactis subsp strain. hordniae NBRC 100931 and L. garvieae JCM 10343, respectively. The presence of E. faecium, E. faecalis, and L. garvieae in Sumbawa horse milk was also reported by Kusdianawati et al. (2020).

The 16S rRNA sequences of each analyzed isolate were then used to see the level of kinship. Moreover, the kinship analysis of LAB isolates from Sumbawa horse milk is presented in a phylogenetic tree (Figure 3). The eight strains of LAB isolates were grouped into four groups, where the strains in each group were similar based on the sequence.

\section{Antioxidant activity of LAB isolated from Sumbawa horse milk}

The samples used for the antioxidant assay were supernatant metabolites extracted from the culture broth of LAB strains in this study. The results of the calculations from the assay performed are shown in Table 2. The DPPH radical scavenging test showed that $L$. garvieae L.22PR metabolite had the highest free radical scavenging activity of $43 \%$, followed by two strains of E. faecium G.6PR and G.5PR at $42 \%$ and $41 \%$, respectively. The lowest percentage of DPPH inhibition was shown by L. lactis subsp hordniae L.19LG metabolite (18\%). The antioxidant activity of the LAB metabolites from Sumbawa horse milk was lower than that of the control vitamin C (79\%).

Table 1. Species of LAB in Sumbawa horse milk

\begin{tabular}{|c|c|c|c|}
\hline Isolate code & Species & Percent identity & Accession number \\
\hline G.5PR & Enterococcus faecium NBRC 100486 & $99.18 \%$ & NR_113904.1 \\
\hline G.6PR & Enterococcus faecium DSM 20477 & $99.59 \%$ & NR_114742.1 \\
\hline G.18LG & Enterococcus durans 98D & $99.19 \%$ & NR_036922.1 \\
\hline G.20LG & Enterococcus faecium ATCC 19434 & $99.45 \%$ & NR_115764.1 \\
\hline G.19PR & Enterococcus faecalis ATCC 19433 & $99.05 \%$ & NR_115765.1 \\
\hline L.19LG & Lactococcus lactis subsp. hordniae NBRC 100931 & $99.93 \%$ & NR_113958.1 \\
\hline L.22PR & Lactococcus garvieae JCM 10343 & $98.40 \%$ & NR_113268.1 \\
\hline L.24PR & Enterococcus faecalis NBRC 100480 & $98.95 \%$ & NR_113902.1 \\
\hline
\end{tabular}

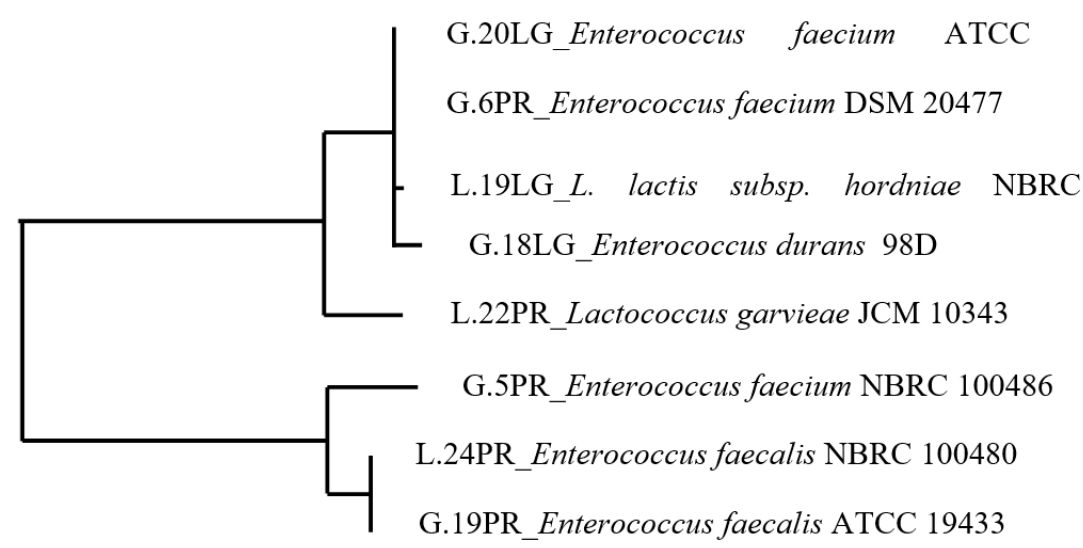

Figure 3. Phylogenetic tree of LAB isolates of Sumbawa horse milk based on 16S rRNA sequence 


\section{Antidiabetic activity of LAB isolated from Sumbawa horse milk}

The inhibitory activities obtained in the present study were ranged between 26 to $45 \%$ (Table 3). The highest inhibitory activity was shown by the strains E. faecium G.6PR and L. garvieae L.22PR at $45 \%$ and $42 \%$, respectively. The strain $L$. lactis L.19LG showed the lowest $\alpha$-glucosidase enzyme inhibitory activity, which was $30 \%$. The activity of the control acarbose in inhibiting the $\alpha$ glucosidase enzyme was $74 \%$.

\section{Discussion}

Next-generation sequencing (NGS) using Illumina is the most widely applied technique in metagenomic studies for analyzing microbial diversity and functional analysis profiles (Jatmiko et al. 2019). NGS is the most effective approach technology for individual classification to particular taxa and allowed finer characterization of bacterial genomes as well as deeper taxonomic recognition of complex microbiomes (Nimnoi and Pongsilp 2020). The hypervariable V3-V4 region in the $16 \mathrm{~S}$ rRNA gene is a target of PCR amplification that can provide information about the bacterial community profile more accurately than the hypervariable V1-V3 region (Teng et al. 2018).

Table 2. Results of antioxidant assay of LAB isolated from Sumbawa horse milk

\begin{tabular}{lll}
\hline $\begin{array}{l}\text { Isolate } \\
\text { code }\end{array}$ & Sample & Inhibition \\
\hline Control + & Vitamin C & $79 \% \pm 0.013^{\mathrm{d}}$ \\
Control - & M17 Broth media & $0 \%$ \\
G.5PR & Enterococcus faecium NBRC 100486 & $41 \% \pm 0.054^{\mathrm{c}}$ \\
G.6PR & Enterococcus faecium DSM 20477 & $42 \% \pm 0.23^{\mathrm{c}}$ \\
G.18LG & Enterococcus durans 98D & $31 \% \pm 0.052^{\mathrm{bc}}$ \\
G.20LG & Enterococcus faecium ATCC 19434 & $38 \% \pm 0.106^{\mathrm{c}}$ \\
G.19PR & Enterococcus faecalis ATCC 19433 & $13 \% \pm 0.146^{\mathrm{a}}$ \\
L.19LG & Lactococcus lactis subsp. hordniae & $18 \% \pm 0.071^{\mathrm{ab}}$ \\
& NBRC 100931 & \\
L.22PR & Lactococcus garvieae JCM 10343 & $43 \% \pm 0.150^{\mathrm{c}}$ \\
L.24PR & Enterococcus faecalis NBRC 100480 & $38 \% \pm 0.056^{\mathrm{c}}$ \\
\hline N.
\end{tabular}

Note: Result followed by the same letter show no significant difference in the one-way ANOVA test, $\alpha=0.05$

Table 3. Results of $\alpha$-glucosidase inhibition assay of LAB Isolated from Sumbawa horse milk

\begin{tabular}{lll}
\hline $\begin{array}{l}\text { Isolate } \\
\text { code }\end{array}$ & Sample & Inhibition \\
\hline Control + & Akarbosa & $74 \% \pm 0,044^{\mathrm{d}}$ \\
Control - & M17 Broth media & $0 \%$ \\
G.5PR & Enterococcus faecium NBRC 100486 & $34 \% \pm 0,016^{\mathrm{b}}$ \\
G.6PR & Enterococcus faecium DSM 20477 & $45 \% \pm 0,028^{\mathrm{c}}$ \\
G.18LG & Enterococcus durans 98D & $30 \% \pm 0,017^{\mathrm{ab}}$ \\
G.20LG & Enterococcus faecium ATCC 19434 & $31 \% \pm 0,024^{\mathrm{ab}}$ \\
G.19PR & Enterococcus faecalis ATCC 19433 & $35 \% \pm 0,030^{\mathrm{b}}$ \\
L.19LG & Lactococcus lactis subsp. hordniae & $30 \% \pm 0,037^{\mathrm{ab}}$ \\
& NBRC 100931 & \\
L.22PR & Lactococcus garvieae JCM 10343 & $42 \% \pm 0,007^{\mathrm{c}}$ \\
L.24PR & Enterococcus faecalis NBRC 100480 & $31 \% \pm 0,041^{\mathrm{ab}}$ \\
\hline Ner
\end{tabular}

Note: Result followed by the same letter show no significant difference in the one way anova test, $\alpha=0,05$
Research on the bacterial community in Sumbawa horse milk conducted by Jatmiko et al. (2019) also detected Lactobacillales and Bacillales. The abundant families that dominate bacteria in Sumbawa horse milk include Enterococcaceae and Streptococcaceae. At the genus level, the enormous bacteria belong to Lactococcus. Moreover, the abundance of bacteria at the species level in Sumbawa horse milk was dominated by LAB Enterococcus durans as the largest species found, followed by $L$. garvieae and $L$. lactis. Lactococcus and Enterococccus spp. are found in abundant quantities in dairy products (Hou et al. 2015). Both genera have been reported to dominate the bacterial population in breast milk (Mehanna et al. 2013) and Colombian fermented cow's milk (Chaves-López et al. 2011). The abundance of these genera in livestock milk can be affected by environmental conditions on the farm. A study on the effect of animal husbandry practices on the abundance of bacteria in goat milk (Tormo et al. 2015) reported that Enterococcus sp. was abundant in milk products from most farms that did not separate the pen from the milking location. On the other hand, farms that are separated between cages and milking sites have a high abundance of Lactococcus spp. Direct contact between the milking site and the pen or the presence of hay in the pen seems to increase the inoculation of Enterococcus in milk.

Enterococcus is often the dominant genus of LAB found in fermented food and milk products, which $E$. faecalis, E. faecium, and E. durans are common species, especially in dairy products (Franz et al. 2011). E. faecium has antibacterial and antifungal activity against pathogenic microbes in the mouth, Streptococcus mutans and Candida albicans (Ng et al. 2020). E. faecium isolated from goat's milk is known to produce bacteriocins which can inhibit the growth of Listeria (Chanos and Williams 2011). Bacteriocins can cause cell membrane damage as indicated by the destabilization of cell membrane permeability (Todorov et al. 2010). A nosocomial bacteria E. faecalis is also known to produce a bacteriocin compound that inhibits hyphal morphogenesis, biofilm formation, and C. albicans virulence (Abrantes et al. 2011; Chanos and Williams 2011; Graham et al. 2017). Meanwhile, E. durans isolated from traditional fermented Mongolian cream has been reported to express an enzyme from the cholylglycine hydrolase family ( $\mathrm{Li}$ et al. 2018). The enzyme catalyzes the glycine and taurine bile salts which are conjugated to amino acid and bile acid residues; thus, it can reduce cholesterol levels in the body (Begley et al. 2006).

Lactococcus is a typical bacterial genus present in plant milk products and biofilms in milking machines (Dalmasso et al. 2009). L. lactis is a bacterial strain from the genus Lactococcus that has the status of Qualified Presumption of Safety (QPS) and Generally Recognized as Safe (GRAS) (Yazdankhah et al. 2016). In its use in the food and health sectors, L. lactis has few reports as an opportunistic pathogen (Chien and Lee 2007). This strain produces the lactic acid compound that can suppress the growth of pathogens. Thus, L. lactis is widely used as starter bacteria in fermented milk products (Volzing et al. 2013). Moreover, bacteriocin nisin from L. lactis is widely used as a food preservative (Liu et al. 2017). In the field of genetic 
and medical engineering, L. lactis is widely used as a host cell in heterologous protein expression (Noreen et al. 2011). Lactococcus garvieae is a type of LAB found as a pathogen in fish and various other marine and freshwater species. These species have also been isolated from other animals, such as ruminants with subclinical mastitis and pigs with pneumonia (Tejedor et al. 2011). Although many have been reported as pathogens, there are strains of $L$. garvieae known to produce bacteriocins, including $L$. garvieae LG34 (Gao et al. 2015). This strain has a bacteriocin, namely garvieacin LG34, which can inhibit the growth of Listeria monocytogenes and several other strains of L. garvieae (Tosukhowong et al. 2012). A study by Ayyash et al. (2020) reported that L. garvieae produced exopolysaccharides which had potential as antitumor, antioxidant, antidiabetic, and antipathogenic.

As mentioned earlier, the antioxidant activity of LAB in Sumbawa horse milk was determined using the DPPH method. The DPPH method has several advantages, including easy, simple, fast, reproducible, suitable for samples with a particular polarity, sensitive, and only requires a small number of samples (Ridho 2013). Free radical scavenging is done by measuring the decrease in absorbance of DPPH in ethanol solvent by the test sample, which converts the purple color of DPPH into yellow. The decrease in the absorbance of DPPH is proportional to the number of radicals captured by the test sample (Astuti 2009). The ability of free radical scavenging by the test sample can be influenced by the extraction method of LAB cells and the concentration of metabolite compounds used (Zhao et al. 2015). Manguntungi et al. (2020) reported that a high antioxidant activity (71\%) of LAB isolated from masin (a fermented sauced) was shown by the highest concentration $(500 \mu \mathrm{g} / \mathrm{mL})$ of masin.

Compounds that thought to play a role in binding DPPH free radicals are exopolysaccharides derived from LAB (Seo et al. 2015). The antioxidant activity of L. garvieae in dairy products has been reported by Ayyash et al. (2020). The exopolysaccharide (EPS) produced by L. garvieae had a DPPH inhibitory activity of $51.92 \%$ at a $5 \mathrm{mg} / \mathrm{mL}$ concentration and increased to $67.52 \%$ when the EPS concentration was increased to $10 \mathrm{mg} / \mathrm{mL}$. The DPPH inhibitory activity of the EPS produced by E. faecium was $38.4 \%$ at a sample concentration of $8 \mathrm{mg} / \mathrm{mL}$ (Abdhul et al. 2014). Exopolysaccharides can bind reactive oxygen and free radicals (Zhou et al. 2019). EPS in L. lactis subsp. lactis showed the same antioxidant activity as control ascorbic acid in tests conducted by Pan and May (2010). Kodali and Sen (2008) reported strong superoxide and hydroxyl radical activity in vitro on EPS of the probiotic strain B. coagulans. However, the effect of the amount of EPS production on LAB in antioxidant activity has not been further studied yet (Zhang et al. 2017b).

The inhibition ability of $\alpha$-glucosidase activity was influenced by the concentration of the metabolite compounds used (Pratama et al. 2015). The high concentration of the compound increase the chance of the inhibitor to close the active site of the enzyme and bind to the enzyme and the enzyme-substrate complex. The inhibition of $\alpha$-glucosidase by LAB isolated from fermented milk was reported previously by Graham et al. (2019) with the value of $33.41 \%$. An investigation by Ramchandran and Shah (2008) reported that the inhibitory activity of $\alpha$-glucosidase from the TCA filtrate of $L$. casei 2607, L. acidophilus 33200, L. delbrueckii ssp. Bulgaricus 1092, and B. longum 5022 were good with high $\alpha$ glucosidase inhibitory activities $(>80 \%)$. It seemed that the inhibitory activity of $\alpha$-glucosidase resulted from exopolysaccharides produced by LAB (Ramchadan and Shah 2009). The principle mechanism of EPS in inhibiting $\alpha$-glucosidase activity is the same as acarbose acting. EPS on LAB in the digestive system can attach to the intestinal mucosa surface to suppress the growth of pathogenic bacteria (Patten and Laws 2015). In addition to EPS, other compounds that are thought to play a role in $\alpha$-glucosidase inhibition are proteins (Lacroix and Li-Chan 2013). Muganga et al. (2015) showed that the presence of $\alpha$ glucosidase inhibitory activity from cell extracts of several Lactobacillus sp. grown in skim milk media with varying results was due to the different proteolytic properties of each isolate.

In conclusion, analysis of the diversity of indigenous bacteria in Sumbawa horse milk detected at least 7 types of phylum, with the two greatest relative abundance phylum including Proteobacteria $(0.641 \%)$ and Firmicutes $(0.327 \%)$. Of the 11 species detected based on the 10 largest genera, Enterococcus durans (39.01\%) had the highest abundance, followed by Lactococcus garvieae $(30.13 \%)$ and Lactococcus lactis (19.85\%). Eight LAB isolates from Sumbawa horse milk identified as different strains, including E. faecium DSM 20477, E. faecium NBRC 100486, E. faecium ATCC 19434, E. durans 98D, E. faecalis ATCC 19433, E. faecalis NRBC 100480, L. lactis subsp. hordniae NBRC 100931, and L. garvieae JCM 10343. The highest antioxidant activity was shown by the L. garvieae L.22PR strain with a DPPH radical binding percentage of $43 \%$, while the highest antidiabetic activity was shown by the E. faecium G.6PR strain with $45 \% \alpha$ glucosidase inhibition.

\section{ACKNOWLEDGEMENTS}

This study was fully funded and supported by the project of Prioritas Nasional (PN) Obat 2019, Research Center for Biotechnology, Indonesian Institute of Sciences (LIPI), Cibinong, Bogor, Indonesia and Indonesia Endowment Fund for Education (LPDP-Lembaga Pengelola Dana Pendidikan).

\section{REFERENCES}

Abdhul KM, Ganesh S, Shanmughapriya M, Kanagavel K, Anbarasu K, Natarajaseenivasan. 2014. Antioxidant Activity of Exopolysaccharide from Probiotic Strain Enterococcus faecium (BDU7) from Ngari. Intl J Biol Macromol 70 (1): 450-454. DOI: 10.1016/j.ijbiomac.2014.07.026.

Abrantes MCM, de Fátima Lopes J, Kok. 2011. Impact of Manganese, Copper and Zinc Ions on the Transcriptome of the Nosocomial Pathogen Enterococcus faecalis V583. PLoS One 6 (10): e26519. DOI: 10.1371/journal.pone.0026519. 
Antara NSIN, Dibia WR, Aryanta. 2009. Karakterisasi bakteri asam laktat yang diisolasi dari susu Kuda Bima. Agritech 29 (1): 1-9. [Indonesian]

Astuti, N.Y. 2009. Uji Aktivitas Penangkap Radikal DPPH oleh Analog Kurkumin Monoketon dan N-Heteroalifatik Monoketon. [Dissertation]. Univerversitas Muhammadiyah Surakarta, Sukoharjo. [Indonesian]

Ayyash M Abu-Jdayil B, Itsaranuwat P, Almazrouei N, Galiwango E, Esposito Y, Hunashal F, Hamed Z, Najjar. 2020. Exopolysaccharide Produced by the Potential Probiotic Lactococcus garvieae C47: Structural Characteristics, Rheological Properties, Bioactivities and Impact on Fermented Camel Milk. Food Chem 333: 127418. DOI: 10.1016/j.foodchem.2020.127418.

Begley M, Hill C, Gahan CG. 2006. Bile Salt Hydrolase Activity in Probiotics. Appl Environ Microbiol 72 (3): 1729-1738. DOI: 10.1128/AEM.72.3.1729-1738.2006.

Chanos P, Williams DR. 2011. Anti-Listeria bacteriocin-producing bacteria from raw ewe's milk in Northern Greece. J Appl Microbiol 110 (3): 757-768. DOI: 10.1111/j.1365-2672.2010.04932.x

Chaves-López C, Serio A, Martuscelli M, Paparella A, Osorio-Cadavid E, Suzzi G. 2011. Microbiological characteristics of Kumis, a traditiona fermented Colombian milk, with particular emphasis on Enterococci population. Food Microbiol 28 (5): 1041-1047. DOI: 10.1016/j.fm.2011.02.006

Chien LJ, Lee CK. 2007. Hyaluronic acid production by recombinan Lactococcus lactis. Appl Microbiol Biotechnol 77 (2): 339-346. DOI: 10.1007/s00253-007-1153-z.

Dalmasso M, Hennequin D, Duc C, Demarigny Y. 2009. Influence of Backslopping on the acidifications curves of "Tomme" type cheeses made during 10 successive days. J Food Eng 92 (1): 50-55. DOI: 10.1016/j.jfoodeng.2008.10.019

Doyle JJ, Doyle JL. 1990. Isolation of plant DNA from fresh tissue. Focus 12 (1): 39-40. DOI: 10.1007/978-3-642-83962-7_18.

Franz CM, Huch M, Abriouel H, Holzapfel W, Gálvez A. 2011. Enterococci as probiotics and their implications in food safety. Intl J $\begin{array}{lllll}\text { Food } & \text { Microbiol } 151 & \text { (2): } & 125-140 . & \text { DOI: }\end{array}$ 10.1016/j.ijfoodmicro.2011.08.014.

Gao Y, Li D, Liu S, Zhang L. 2015. Garviecin LG34, a Novel Bacteriocin Produced by Lactococcus garvieae Isolated from Traditional Chinese Fermented Cucumber. Food Control 50: 896-900. DOI 10.1016/j.foodcont.2014.10.040.

Graham CE, Cruz MR, Garsin DA, Lorenz MC. 2017. Enterococcus faecalis Bacteriocin EntV inhibits hyphal morphogenesis, biofilm formation, and virulence of Candida albicans. Proc Natl Acad Sci USA 114 (17): 4507-4512. DOI: 10.1073/pnas.1620432114.

Graham K, Rea R, Simpson P, Stack H. 2019. Enterococcus faecalis milk fermentates display antioxidant properties and inhibitory activity towards key enzymes linked to hypertension and hyperglycaemia. J Funct Foods 58: 292-300. DOI: 10.1016/j.jff.2019.04.052.

Handelsman J. 2004. Metagenomics: application of genomics to uncultured microorganisms. Microbiol Mol Biol Rev 68 (4): 669-685. DOI: 10.1128/MMBR.68.4.669-685.2004.

Jatmiko Y, Mustafa I, Ardyati T. 2019. Profile of microbial community of naturally fermented sumbawa mare's milk using Next-Generation Sequencing. Berkala Penelitian Hayati 24 (2): 65-69.

Kodali VP, Sen R. 2008. Antioxidant and free radical scavenging activities of an exopolysaccharide from a probiotic bacterium. Biotechnol J Healthcare Nutr Technol 3 (2): 245-251. DOI: 10.1002/biot.200700208

Kusdianawati, Mustopa AZ, Fatimah, Budiarto BR. 2020. Genetic diversity of Lactic Acid Bacteria from Sumbawa horse milk, Indonesia. Biodiversitas 21 (7): 3225-3233. DOI: 10.13057/biodiv/d210744.

Laily IN, Utami R, Widowati E. 2013. Isolasi dan karakterisasi bakteri asam laktat penghasil Riboflavin dari produk fermentasi sawi asin. Jurnal Aplikasi Teknologi Pangan 2 (4): 179-184. [Indonesian]

Lacroix IM, Li-Chan EC. 2013. Inhibition of Dipeptidyl Peptidase (DPP)IV and $\alpha$-glucosidase activities by pepsin-treated whey proteins. J Agric Food Chem 61(31): 7500-7506. DOI: 10.1021/jf401000s.

Li B, Evivie SE, Jin D, Meng Y, Li N, Yan F, Huo G, Liu F. 2018. Complete genome sequence of Enterococcus durans KLDS6. 0933, a potential probiotic strain with high cholesterol removal ability. Gut Pathogens 10 (32): 1-6. DOI: 10.1186/s13099-018-0260-y.

Liu J, Zhou J, Wang L, Ma Z, Zhao G, Ge Z, Zhu H, Qiao J. 2017 Improving nitrogen source utilization from defatted soybean meal for nisin production by enhancing proteolytic function of Lactococcus lactis F44. Sci Rep 7 (1): 1-13. DOI: 10.1038/s41598-017-06537-w.

Manguntungi B, Perkasa AS, Kusdianawati, Hastuti HP, Yulianti, Muhamad A. 2018. Isolasi bakteri asam laktat dari susu kuda liar dan potensi antibakteri pada susu kuda liar Sumbawa. Biota: Jurnal Ilmiah Ilmu-Ilmu Hayati 3 (2): 62-69. [Indonesian]

Manguntungi AB, Saputri DS, Mustopa AZ, Ekawati N, Nurfatwa M, Prastyowati A, Irawan S, Vanggy LR, Fidien KA. 2020. Antidiabetic, antioxidants and antibacterial activities of Lactic Acid Bacteria (LAB) from Masin (fermented sauced from Sumbawa, West Nusa Tenggara, Indonesia). Annales Bogorienses 24 (1): 27-34. DOI: 10.14203/ann.bogor.2020.v24.n1.27-34.

Mehanna NS, Tawfik NF, Salem MM, Effat BA, Gad El-Rab DA. 2013. Assessment of potential probiotic bacteria isolated from breast milk. Middle-East J Sci Res 14 (3): 354-360. DOI: 10.5829/idosi.mejsr.2013.14.3.2102.

Muganga L, Liu X, Tian F, Zhao J, Zhang H, Chen W. 2015. Screening for Lactic Acid Bacteria based on antihyperglycaemic and probiotic potential and application in synbiotic set yoghurt. J Funct Foods 16: 125-136. DOI: 10.1016/j.jff.2015.04.030.

Ng ZJ, Zarin MA, Lee CK, Phapugrangkul P, Tan JS. 2020. Isolation and characterization of Enterococcus faecium DSM 20477 with ability to secrete antimicrobial substance for the inhibition of oral pathogen Streptococcus mutans UKMCC 1019. Arch Oral Biol 110: 104617. DOI: 10.1016/j.archoralbio.2019.104617.

Nimnoi P, Pongsilp N. 2020. Marine bacterial communities in the Upper Gulf of Thailand assessed by illumina next-generation sequencing platform. BMC Microbiol 20: 9. DOI: 10.1186/s12866-020-1701-6.

Noreen N, Hooi WY, Baradaran A, Rosfarizan M, Sieo CC, Rosli MI, Yusoff K, Raha AR. 2011. Lactococcus lactis M4, a potential host for the expression of heterologous proteins. Microbial Cell Factories 10: 28. DOI: $10.1186 / 1475-2859-10-28$

Nuraida L. 2015. A review: health promoting lactic acid bacteria in traditional Indonesian Fermented Foods. Food Sci Hum Wellness 4 (1): 47-55. DOI: 10.1016/j.fshw.2015.06.001.

Pan D, Mei X. 2010. Antioxidant activity of an exopolysaccharide purified from Lactococcus lactis subsp. lactis 12. Carbohydrate Polymers 80 (3): 908-914. DOI: 10.1016/j.carbpol.2010.01.005

Patten DA, Laws AP. 2015. Lactobacillus-produced exopolysaccharides and their potential health benefits: a review. Beneficial Microbes 6 (4): 457-471. DOI: 10.3920/BM2014.0117.

Pratama Y, Sarjono PR, Mulyani NS. 2015. Skrining metabolit sekunder bakteri endofit yang berfungsi sebagai antidiabetes dari daun mimba (Azadirachta indica). Jurnal Kimia dan Aplikasi Sains 18 (2): 73-78. [Indonesian]

Ramchandran L, Shah NP. 2008. Proteolytic profiles and angiotensin-i converting enzyme and $\alpha$-glucosidase inhibitory activities of selected Lactic Acid Bacteria. J Food Sci 73(2): 75-81. DOI: 10.1111/j.17503841.2007.00643.x

Ramchandran L, Shah NP. 2009. Effect of exopolysaccharides and inulin on the proteolytic, Angiotensin-I-converting enzyme-and aglucosidase inhibitory activities as well as on textural and rheological properties of lowfat yogurt during refrigerated storage. Dairy Sci Technol 89 (1): 583-600. DOI:10.1051/dst/2009039.

Rattanachaikunsopon P, Phumkhachorn P. 2010. Lactic Acid Bacteria: their antimicrobial compounds and their uses in food production. Ann Biol Res 1 (4): 218-228

Reni S, Sumarno S, Widjajanto E. 2013. Susu kuda Sumbawa meningkatkan respon imun seluler makrofag peritoneal mencit terhadap Salmonella typhimurium. Jurnal Kedokteran Brawijaya 26 (1): 14-19. [Indonesian]

Ridho EA. 2013. Uji aktivitas antioksidan ekstrak n-heksan buah lakum (Cayratia trifolia) dengan metode DPPH (2, 2-difenil-1pikrilhidrazil). [Dissertation]. Tanjungpura University, Pontianak. [Indonesian]

Seo BJ, Bajpai VK, Rather IA, Park YH. 2015. Partially purified exopolysaccharide from Lactobacillus plantarum YML009 with total pphenolic content, antioxidant and free radical scavenging efficacy. Indian J Pharmaceut Educat Res 49 (4): 282-292. DOI: 10.5530/ijper.49.4.6

Setyowati EP, Laili FN, Iravati S. 2012. Sumbawa horse milk typical Indonesian antibacterial cosmetic ingredients against acne (Staphylococcus epidermidis). Tradit Med J 19 (2): 74-79.

Shimada K, Fujikawa K, Yahara K, Nakamura T. 1992. Antioxidative properties of xanthan on the autoxidation of soybean oil in 
Cyclodextrin emulsion. J Agric Food Chem 40 (6): 945-948. DOI: 10.1021/jf00018a005.

Sujaya IN, Aryantini NPD, Nursini NW, Cakrawati CID, Juliasari NLME, Dwipayanti NMU, Ramona Y. 2012. Eksopolisakarida dari Lactobacillus sp. isolat susu kuda Sumbawa dan potensinya sebagai prebiotik. Jurnal Veteriner 13 (2): 136-144. [Indonesian]

Sujaya IN, Dwipayanti IMU, Suariani NLP, Widarini NP, Nocianitri KA, Nursini NW. 2008a. Potensi Lactobacillus spp. isolay susu kuda Sumbawa sebagai probiotik. Jurnal Veteriner 9 (1): $33-40$ [Indonesian]

Sujaya N, Ramona Y, Widarini NP, Suariani NP, Dwipayanti NMU, Nocianitri KA, Nursini NW. 2008b. Isolasi dan karakterisasi bakteri asam laktat dari susu kuda Sumbawa. Jurnal Veteriner 9 (2): 52-59. [Indonesian]

Tagliazucchi D, Martini S, Solieri L. 2019. Bioprospecting for bioactive peptide production by Lactic Acid Bacteria isolated from fermented dairy food. Fermentation 5 (4): 96. DOI: 10.3390/fermentation5040096.

Tejedor JL, Vela AI, Gibello A, Casamayor A, Domínguez L, FernándezGarayzábal JF. 2011. A genetic comparison of pig, cow and trout isolates of Lactococcus garvieae by PFGE analysis. Lett Appl Microbiol 53 (1): 614-619. DOI: 10.1111/j.1472-765X.2011.03153.x.

Teng F, Nair SSD, Zhu P, Li S, Huang S, Li X, Xu J, Yang F. 2018 Impact of DNA Extraction method and targeted 16S-rRNA Hypervariable region on oral microbiota profiling. Sci Rep 8 (1): 16321. DOI: $10.1038 / \mathrm{s} 41598-018-34294-x$.

Todorov SD, Wachsman M, Tomé E, Dousset X, Destro MT, Dicks LMT, Franco DGM, Drider D. 2010. Characterisation of an antiviral pediocin-like bacteriocin produced by Enterococcus faecium. Food Microbiol 27 (7): 869-879. DOI: 10.1016/j.fm.2010.05.001.

Tormo H, Lekhal DAH, Roques C. 2015. Phenotypic and genotypic characterization of Lactic Acid Bacteria isolated from raw goat milk and effect of farming practices on the dominant species of Lactic Acid Bacteria. Intl J Food Microbiol 210: 9-15. DOI: 10.1016/j.ijfoodmicro.2015.02.002

Tosukhowong A, Zendo T, Visessanguan W, Roytrakul S, Pumpuang L, Jaresitthikunchai J, Sonomoto K. 2012. Garvieacin Q, a Novel Class II Bacteriocin from Lactococcus garvieae BCC 43578. Appl Environ Microbiol 78 (5): 1619-1623. DOI: 10.1128/AEM.06891-11.
Volzing K, J. Borrero, M.J. Sadowsky, Y.N. Kaznessis. 2013. Antimicrobial peptides targeting gram-negative pathogens, produced and delivered by Lactic Acid Bacteria. ACS Synthetic Biol 2 (11): 643-650. DOI: $10.1021 / \mathrm{sb} 4000367$.

Ward TL, Hosid S, Ioshikhes I, Altosaar I. 2013. Human milk metagenome: a functional capacity analysis. BMC Microbiol 13: 116. DOI: 10.1186/1471-2180-13-116.

Wyszyńska A, Kobierecka P, Bardowski J, Jagusztyn-Krynicka EK. 2015. Lactic Acid Bacteria: 20 years exploring their potential as live vectors for mucosal vaccination. Appl Microbiol Biotechnol 99 (7): 29672977. DOI: 10.1007/s00253-015-6498-0.

Yazdankhah SP, Grahek-Ogden D, Eckner KF, Kapperud G, Lassen JF, Narvhus J, Nesbakken T, Robetson L, Rosnes JT, Skjerdal T, Vold L, Skjerve E, Wasteson Y. 2016. Risk assessment of Lactococcus lactis W58 used as "other substances". opinion of the panel on biological hazards of the Norwegian Scientific Committee for Food Safety. VKM Report. 28: 1-20.

Zahratunnisa N, Elya B, Noviani A. 2017. Inhibition of alpha-glucosidase and antioxidant test of stem bark extracts of Garcinia fruticosa Lauterb. Pharmacognosy J 9 (2): 273-275. DOI: 10.5530/pj.2017.2.46.

Zhang F, Wang Z, Lei F, Wang B, Jiang S, Peng Q, Zhang J, Shao Y. 2017b. Bacterial diversity in goat milk from the Guanzhong Area of China. J Dairy Sci 100 (10): 7812-7824. DOI: 10.3168/jds.201713244

Zhang J, Zhao X, Jiang Y, Zhao W, Guo T, Cao, Teng J, Hao X, Hao J, Yang Z. 2017a. Antioxidant status and gut microbiota change in an aging mouse model as influenced by exopolysaccharide produced by Lactobacillus plantarum YW11 isolated from Tibetan kefir. J Dairy Sci 100 (8): 6025-6041. DOI: 10.3168/jds.2016-12480.

Zhao Q, Dong B, Chen J, Zhao B, Wang X, Wang L, Zha S, Wang Y, Zhang J, Wang Y. 2015. Effect of drying methods on physicochemical properties and antioxidant activities of wolfberry (Lycium barbarum) Polysaccharide. Carbohydrate Polymers 127 (1): 176-181. DOI: 10.1016/j.carbpol.2015.03.041.

Zhou Y, Cui Y, Qu X. 2019. Exopolysaccharides of Lactic Acid Bacteria: structure, bioactivity and associations: a review. Carbohydrate Polymers 207: 317-332. DOI: 1 0.1016/j.carbpol.2018.11.093. 